\title{
Influence of the geometry of ceramic specimens on biaxial flexural strength: experimental testing and finite element analysis
}

\section{(Influência da geometria do corpo de prova cerâmico na resistência flexural biaxial: ensaio experimental e análise de elementos finitos)}

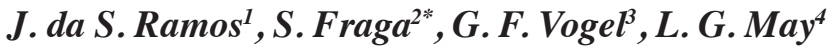 \\ ${ }^{1}$ Dentistry College; ${ }^{2}$ Graduate Program in Dental Science; ${ }^{3}$ Industrial Technical High School; \\ ${ }^{4}$ Department of Restorative Dentistry, Universidade Federal de Santa Maria, \\ R. Duque de Caxias 1295/803, Santa Maria, RS, Brazil \\ jo.joana.r@hotmail.com, "sara.odonto@yahoo.com.br,gf.vogel@ctism.ufsm.br,liligmay@gmail.com
}

\begin{abstract}
This study evaluated the influence of the geometry of ceramic specimens (disc vs. square plate) on the biaxial flexural strength (BFS) using an experimental set and finite element analysis (FEA). Leucite glass-ceramic blocks were used in the preparation of disc $(D ; n=14)$ and square plate $(S ; n=13)$ specimens with the same lower (tensile) surface area. The specimens were subjected to a piston-on-three-ball flexural test (ISO 6872:2008). To calculate the BFS of the S group, the specimen radius, indicated by the ISO 6872:2008 formula for discs, was replaced by half of the side length. FEA compared the pattern of stress distribution and the first principal stress between D and S specimens having the same and different lower (tensile) surface area. Student's t-test showed no difference $(\mathrm{p}=0.85)$ in the BFS between $\mathrm{D}(95.0 \pm 9.6 \mathrm{MPa})$ and $\mathrm{S}(84.3 \pm 10.3 \mathrm{MPa})$. FEA indicated a similar pattern of stress distribution, with almost no difference in the first principal stress of discs and square plates with the same lower (tensile) surface area. In the experimental condition investigated, square plate ceramic specimens can be used in piston-on-three-ball tests. For the calculation of the BFS, the specimen radius may be replaced by half side length of the square specimen.
\end{abstract}

Keywords: biaxial flexural strength, finite element method, dental ceramic, specimen shape.

\section{Resumo}

O presente estudo avaliou a influência da geometria do corpo de prova cerâmico (disco vs. quadrado) na resistência flexural biaxial $(R F B)$, por meio de ensaio experimental e análise de elementos finitos (AEF). Blocos de vitrocerâmica reforçada por leucita foram utilizados na confecção de corpos de prova no formato de discos $(D ; n=14)$ e quadrados $(Q ; n=13)$, com mesma área na superfície inferior (superfície sujeita à tração durante o ensaio). Os corpos de prova foram submetidos a ensaio de flexão biaxial pistão sobre três esferas (ISO 6872:2008). Para calcular a RFB do grupo Q, o raio do corpo de prova, indicado pela fórmula da ISO $6872: 2008$ para discos, foi substituído por metade do lado do quadrado. AEF foi empregada para comparar o padrão de distribuição de tensões e a primeira tensão principal entre $D$ e $Q$, com áreas iguais e diferentes na superfície inferior (tração). Teste t de Student não mostrou diferença $(p=0,85)$ na RFB entre $D(95,0 \pm 9,6 \mathrm{MPa})$ e $Q(84,3 \pm 10,3 \mathrm{MPa})$. AEF indicou um padrão similar de distribuição de tensões, com quase nenhuma diferença na primeira tensão principal entre $D$ e $Q$ com mesma área na superfície inferior (tração). Na condição experimental testada, corpos de prova cerâmicos no formato de quadrado podem ser usados em ensaio de flexão biaxial pistão sobre três esferas. Para o cálculo da RFB, o raio do espécime pode ser substituído por metade do lado do quadrado. Palavras-chave: resistência à flexão biaxial, análise de elementos finitos, cerâmica dentária, geometria do corpo de prova.

\section{INTRODUCTION}

Fracture strength of brittle materials is a conditional property, since it depends on the presence, size and distribution of defects, testing environment (i.e. dry or wet) and testing methodology [1]. Fracture strength data may provide important information related to the mechanical behavior of dental restorative materials, allowing to compare and to rank different materials. Besides, general dentists can easily understand the concept of strength. Different mechanical tests have been designed to study the fracture behavior of dental restorative materials. The
International Standard for Dentistry Ceramic Materials (ISO 6872:2008) is one of the most reported standards used by the dental scientific community in the studying of dental ceramic materials [2]. This document presents three flexural tests to evaluate the fracture strength of ceramics: three-point bending, four-point bending, and biaxial flexure (piston-on-three-ball configuration) [3]. The main advantage of flexural tests is that a pure state of tensile stress is established on one side of the specimen [4], where failure should initiate (tensile surface), and it is balanced by compression stress on the opposite side [5]. Considering that brittle materials, such as dental ceramics, 
are significantly weaker in tension than in compression [5], tensile strength is a meaningful property to assess the effect of surface treatments (i.e. grinding, sandblasting) in the potential failure of ceramic restorations [6]. The biaxial strength testing of brittle materials has some advantages, compared to the uniaxial testing, such as simpler specimen preparation (since it is not necessary to chamfer the edges), absence of tensile loaded edges (the load is applied in the center of the specimen, away from the edges), and a state of multiaxial loading condition, which does not discriminate cracks in particular orientations [7, 8]. Different configurations of biaxial flexural tests are reported in the literature, as piston-on-three ball, ring-on-ring, ball-onring [9], and ball-on-three-balls [8]. Regarding dental ceramics, ISO 6872:2008 [3] recommends a piston-onthree-ball configuration, in which a disc-shaped specimen is supported by three hardened steel balls with a diameter between 2.5 and $6.5 \mathrm{~mm}$ and positioned $120^{\circ}$ apart on a support circle with a diameter between 10 and $12 \mathrm{~mm}$. The sample is placed concentrically on these supports and the load is applied with a flat punch with a diameter of $1.4 \pm 0.2$ $\mathrm{mm}$ at the center of the specimen.

All-ceramic systems have been widely employed in restorative dentistry due to their ability to mimic natural tooth and their biocompatibility [10]. The use of computeraided design/computer-aided machining (CAD/CAM) technology has allowing the manufacture of indirect allceramic restorations using pre-fabricated ceramic blocks, obtained in an industrial and standardized process, which reduces the incorporation of defects, and results in a more homogeneous material $[11,12]$. CAD/CAM ceramics, such as feldspathic, leucite, lithium disilicate and zirconia, are usually supplied in blocks, with a cuboid geometry, for machining in $\mathrm{CAD} / \mathrm{CAM}$ systems. Therefore, to prepare a ceramic disc for a biaxial flexural test, the researcher needs to ground the block into a cylinder, which will be sawed to obtain disc-shaped specimens. This procedure can be very time-consuming, especially when preparing discs from fully sintered CAD/CAM ceramics. The use of plate instead of disc specimens would eliminate the need of grinding the ceramic block into a cylinder, optimizing the time of preparation of samples for biaxial tests. Therefore, the aim of the present study was to evaluate, in a pistonon-three ball configuration (ISO 6872:2008), the influence of the geometry of ceramic specimens (disc vs. square plate) on the biaxial flexural strength and on the pattern of stress distribution using experimental tests and finite element analysis (FEA). The null hypothesis was that disc and square plate ceramic specimens, with the same lower (tensile) surface area, would show a similar behavior in terms of biaxial flexural strength.

\section{MATERIALS AND METHODS}

Disc vs. square plate ceramic specimens - experimental testing: leucite-reinforced glass-ceramic fully sintered blocks for CAD/CAM (IPS Empress CAD C14L, Ivoclar Vivadent, dimensions: $14 \times 14 \times 18 \mathrm{~mm}$ ) were used in the preparation of discs (group D; $n=14$ ) and square plates (group $\mathrm{S} ; \mathrm{n}=13$ ) specimens. Two blocks were ground into cylinders in a polishing machine (EcoMet/AutoMet 250, Buehler) using 220 and 400 grit silicon carbide paper, and then cut under water irrigation with a diamond saw (Labcut 1010, Extec) to obtain $1.4 \mathrm{~mm}$-thick D specimens with a diameter of $14 \mathrm{~mm}$. The lower (tensile) surface area was $154 \mathrm{~mm}^{2}$. Square plate ceramic specimens ( $\mathrm{S}$ ) were prepared considering that $\mathrm{D}$ and $\mathrm{S}$ specimens should have the same lower (tensile) surface area. Therefore, the side length of the S specimen was set to $12.41 \mathrm{~mm}$, resulting in a lower (tensile) surface area of 154 $\mathrm{mm}^{2}$. Then, two ceramic blocks were cut with the diamond saw, under water irrigation, to obtain a ceramic block with dimensions of $12.41 \times 12.41 \times 18 \mathrm{~mm}$. The lateral sides of the blocks were polished with 400 grit silicon carbide paper. Then, the ceramic blocks were cut to prepare $1.4 \mathrm{~mm}$-thick S specimens with a side length of $12.41 \mathrm{~mm}$. All samples were polished using 400, 600 and 1200 grit silicon carbide paper in the polishing machine, under water cooling, until the thickness of $1.1 \mathrm{~mm}$ was reached, ensuring that the opposing faces were flat and parallel to within $0.05 \mathrm{~mm}$.

The flexural strength of the specimens was determined using a piston-on-three-ball test, according to ISO 6872:2008 [3], in a universal testing machine (DL-1000, Emic). The specimen was positioned on the top of three steel spheres ( $2.5 \mathrm{~mm}$ in diameter, $120^{\circ}$ apart, and forming a circle of 10 $\mathrm{mm}$ in diameter) and the load was applied perpendicular to the center of the top surface of the specimen by a flat tip cylinder steel piston with a diameter of $1.4 \mathrm{~mm}$ at a rate of $0.5 \mathrm{~mm} / \mathrm{min}$. To evenly distribute the contact pressures, a polyethylene film was placed between the supporting balls and the specimen; an adhesive tape was fixed on the compression side of the discs providing an evener contact between the piston and the specimen and preventing the spreading of the fragments after the fracture. The flexural strength, in $\mathrm{MPa}$, was calculated using the equations:

$$
\begin{aligned}
& \sigma=-0.2387 \mathrm{P}(\mathrm{X}-\mathrm{Y}) / \mathrm{d}^{2} \\
& \mathrm{X}=(1+v) \ln (\mathrm{B} / \mathrm{C})^{2}+[(1-v) / 2](\mathrm{B} / \mathrm{C})^{2} \\
& \mathrm{Y}=(1+v)\left[1+\ln (\mathrm{A} / \mathrm{C})^{2}\right]+(1-v)(\mathrm{A} / \mathrm{C})^{2}
\end{aligned}
$$

where, $\mathrm{P}$ is the load at fracture $(\mathrm{N}), \mathrm{d}$ is thickness of the specimens $(1.1 \mathrm{~mm}), v$ is Poisson's ratio $(0.25)$, A is support ball radius $(5 \mathrm{~mm}), B$ is radius of the piston tip $(0.7 \mathrm{~mm})$, and $\mathrm{C}$ is the specimen radius (for $\mathrm{D}$ specimens, $\mathrm{C}=7 \mathrm{~mm}$; for $\mathrm{S}$ specimens, $\mathrm{C}=6.205 \mathrm{~mm}$, corresponding to one-half of the edge length of the square plate specimen). The number of fragments resulted of the fracture of each specimen was recorded.

Disc vs. square plate ceramic specimens - finite element analysis: three-dimensional models were developed using the SolidWorks 2014 software (Dassault Systèmes SolidWorks), simulating D and $\mathrm{S}$ specimens with an equal tensile surface area (Table I, conditions 1 to 4 ) and with the disc radius equal 
to half side length of the square (Table I, conditions 5 to 8 ). Reference lines were designed to simulate the piston used to apply the load, and the supporting balls. Displacement constraints were applied to the supporting balls, which were fixed along the three axes of displacement $(\mathrm{x}, \mathrm{y}, \mathrm{z})$. A compressive distributed loading of $80 \mathrm{~N}$ was applied to the piston reference line. Leucite glass-ceramic was considered a homogeneous, isotropic and linearly elastic material. The following properties were input to the model for the FEA: Young's modulus of $62 \mathrm{GPa}$ [13]; density of $2470 \mathrm{~kg} / \mathrm{m}^{3}$ [13]; Poisson's ratio of 0.25 [3]. Meshing was constituted by 3D tetrahedral elements with curvature base and high quality. After a convergence testing, a maximum element size of 0.2 $\mathrm{mm}$ was chosen, which allowed obtaining eight layers of elements in D specimens and twelve layers of elements in $\mathrm{S}$ specimens. Considering the brittle nature of the ceramic materials, FEA results were analyzed in terms of first principal stress, which was evaluated at a central point located on the tensile surface of the specimens.

Statistical analysis: Student's t-test was used to compare the values of the biaxial flexural strength of the $\mathrm{D}$ and $\mathrm{S}$ groups, as the data presented homogeneity of variances $(\mathrm{p}>0.05$ based on the Levene test) and normal distribution ( $p>0.05$ based on the Shapiro-Wilk test). The number of fragments resulted of the fracture of $\mathrm{D}$ and $\mathrm{S}$ groups was compared by Mann-Whitney test since this variable showed non-normal distribution $(\mathrm{p}<0.05$ based on the Shapiro-Wilk test).

Fractographic analysis: after the mechanical test, the specimens were analyzed in a stereomicroscope; some of them were randomly chosen and subjected to a scanning electron microscopy (SEM) analysis to identify the surface where the fracture initiated.

\section{RESULTS}

The mean values of the flexural strength did not differ significantly $(\mathrm{p}=0.850)$ between $\mathrm{D}(95.0 \pm 9.6 \mathrm{MPa})$ and $\mathrm{S}(84.3 \pm 10.3 \mathrm{MPa})$ groups. The number of fragments did not differ between $\mathrm{D}$ and $\mathrm{S}(\mathrm{p}=0.325)$. D group fractures resulted in 2 pieces for $79 \%$ of the discs and in 3 pieces for $21 \%$ of the samples. $\mathrm{S}$ group fractures resulted in 3 pieces for just one square specimen (8\%), while the others (92\%)

Table I - Conditions simulated in the finite element analysis.

[Tabela I - Condições simuladas na análise de elementos finitos.]

\begin{tabular}{|c|c|c|c|c|c|}
\hline \multirow{2}{*}{\multicolumn{2}{|c|}{$\begin{array}{c}\text { FEA simulation } \\
\text { Surface area }\left(\mathrm{mm}^{2}\right)\end{array}$}} & \multicolumn{2}{|c|}{ Disc } & \multicolumn{2}{|c|}{ Square plate } \\
\hline & & $\begin{array}{l}\text { Surface area } \\
\qquad\left(\mathrm{mm}^{2}\right)\end{array}$ & $\begin{array}{l}\text { Radius } \\
(\mathrm{mm})\end{array}$ & $\begin{array}{l}\text { Surface area } \\
\quad\left(\mathrm{mm}^{2}\right)\end{array}$ & $\begin{array}{l}\text { Half side length } \\
(\mathrm{mm})\end{array}$ \\
\hline \multirow{4}{*}{$\begin{array}{c}\text { Specimens with the same } \\
\text { lower (tensile) surface } \\
\text { area }\end{array}$} & Condition 1 & 113 & 6 & 113 & 5.315 \\
\hline & Condition $2 *$ & 154 & 7 & 154 & 6.205 \\
\hline & Condition 3 & 201 & 8 & 201 & 7.090 \\
\hline & Condition 4 & 254 & 9 & 254 & 7.975 \\
\hline \multirow{4}{*}{$\begin{array}{c}\text { Specimens with different } \\
\text { lower (tensile) surface } \\
\text { areas }\end{array}$} & Condition 5 & 113 & 6 & 144 & 6 \\
\hline & Condition 6 & 154 & 7 & 196 & 7 \\
\hline & Condition 7 & 201 & 8 & 256 & 8 \\
\hline & Condition 8 & 254 & 9 & 324 & 9 \\
\hline
\end{tabular}

* - Simulation of the experimental condition.

Table II - Finite element analysis: first principal stress for disc and square plate specimens with the same lower (tensile) surface area.

[Tabela II - Análise de elementos finitos: primeira tensão principal para discos e quadrados com mesma área na superfície inferior (tração) do corpo de prova.]

\begin{tabular}{ccccc}
\hline FEA simulation & $\begin{array}{c}\text { Radius of the } \\
\text { disc }(\mathrm{mm}) ; \\
\text { surface area } \\
\left(\mathrm{mm}^{2}\right)\end{array}$ & $\begin{array}{c}\text { Half side of the } \\
\text { square plate } \\
(\mathrm{mm}) ; \text { surface } \\
\text { area }\left(\mathrm{mm}^{2}\right)\end{array}$ & $\begin{array}{c}\text { First principal stress } \\
(\mathrm{MPa}) \\
\text { Square plate }\end{array}$ \\
\hline Condition 1 & $6 ; 113$ & $5.315 ; 113$ & 100.47 & 100.60 \\
Condition 2* & $7 ; 154$ & $6.205 ; 154$ & 99.00 & 99.37 \\
Condition 3 & $8 ; 201$ & $7.09 ; 201$ & 98.34 & 98.65 \\
Condition 4 & $9 ; 254$ & $7.975 ; 254$ & 97.93 & 98.00 \\
\hline
\end{tabular}

* - Simulation of the experimental condition. 
Table III - Finite element analysis: first principal stress for disc and square plate specimens with different lower (tensile) surface area, where the disc radius was equivalent to half side length of the square.

[Tabela III - Análise de elementos finitos: primeira tensão principal para discos e quadrados com diferente área na superfície inferior (tração) do corpo de prova, em que o raio do disco foi equivalente à metade do lado do quadrado.]

\begin{tabular}{ccccc}
\hline FEA simulation & $\begin{array}{c}\text { Radius of the } \\
\text { disc }(\mathrm{mm}) ; \\
\text { surface area } \\
\left(\mathrm{mm}^{2}\right)\end{array}$ & $\begin{array}{c}\text { Half side of the } \\
\text { square plate } \\
(\mathrm{mm}) ; \text { surface } \\
\text { area }\left(\mathrm{mm}^{2}\right)\end{array}$ & Dirst principal stress (MPa) & Square plate \\
\hline Condition 5 & $6 ; 113$ & $6 ; 144$ & 100.47 & 99.31 \\
Condition 6 & $7 ; 154$ & $7 ; 196$ & 99.00 & 98.59 \\
Condition 7 & $8 ; 201$ & $8 ; 256$ & 98.34 & 97.57 \\
Condition 8 & $9 ; 254$ & $9 ; 324$ & 97.93 & 97.60 \\
\hline
\end{tabular}
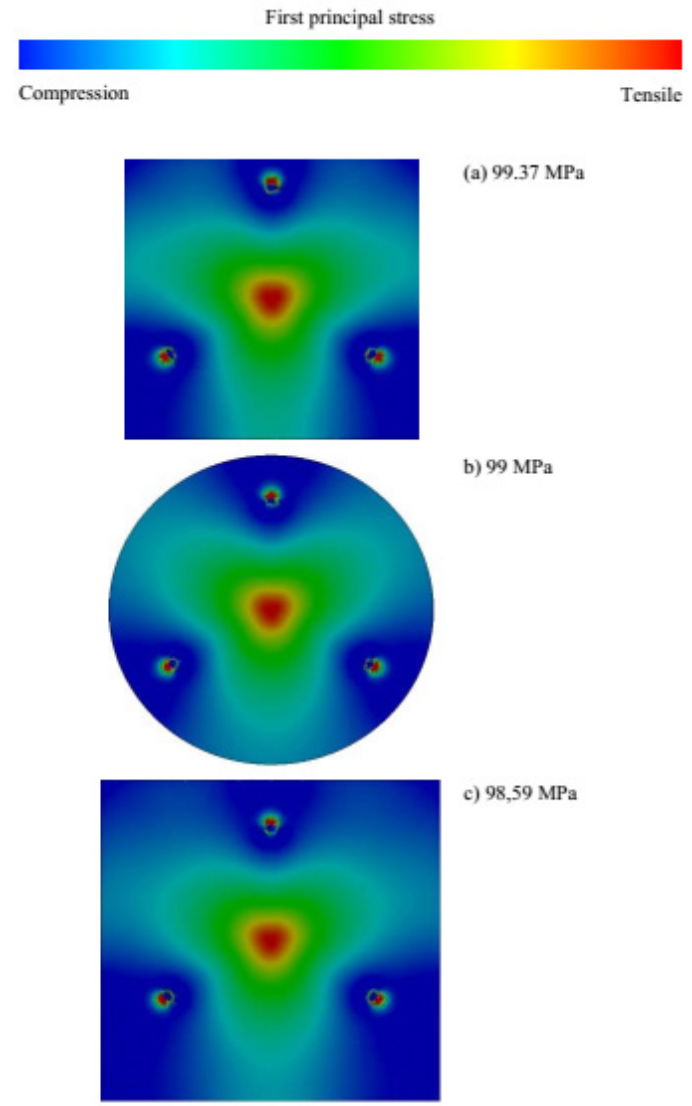

(a) $99.37 \mathrm{MPa}$

b) $99 \mathrm{MPa}$

c) $98,59 \mathrm{MPa}$

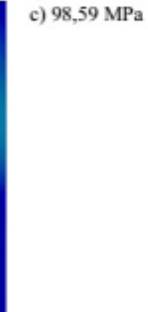

Figure 1: Pattern of stress distribution and first principal stress (measured at a central point) of the surface subjected to tensile stress during the load application in finite element analysis. The images (a) and (b) represent the condition tested in vitro (condition 2). The image (c) shows the square plate specimen with a tensile surface area of $196 \mathrm{~mm}^{2}$, in which the half side of the square was equivalent to the radius of the disc illustrated in (b).

[Figura 1: Padrão de distribuição de tensões e primeira tensão principal (medida no ponto central) da superfície sujeita a tensão de tração durante a aplicação da carga na análise de elementos finitos. As imagens (a) e (b) representam a condição testada in vitro (condição 2). A imagem (c) ilustra um corpo de prova quadrado, com área inferior de $196 \mathrm{~mm}^{2}$, em que metade do lado foi equivalente ao raio do disco ilustrado em (b).] presented 2 pieces. The FEA results are reported in Tables II and III. Almost no difference could be seen between D and $\mathrm{S}$ specimens with the same lower (tensile) surface area (Table II, conditions 1 to 4) in terms of first principal stress. When the disc radius was equivalent to half side length of the square (Table III, conditions 1 to 5), this difference had
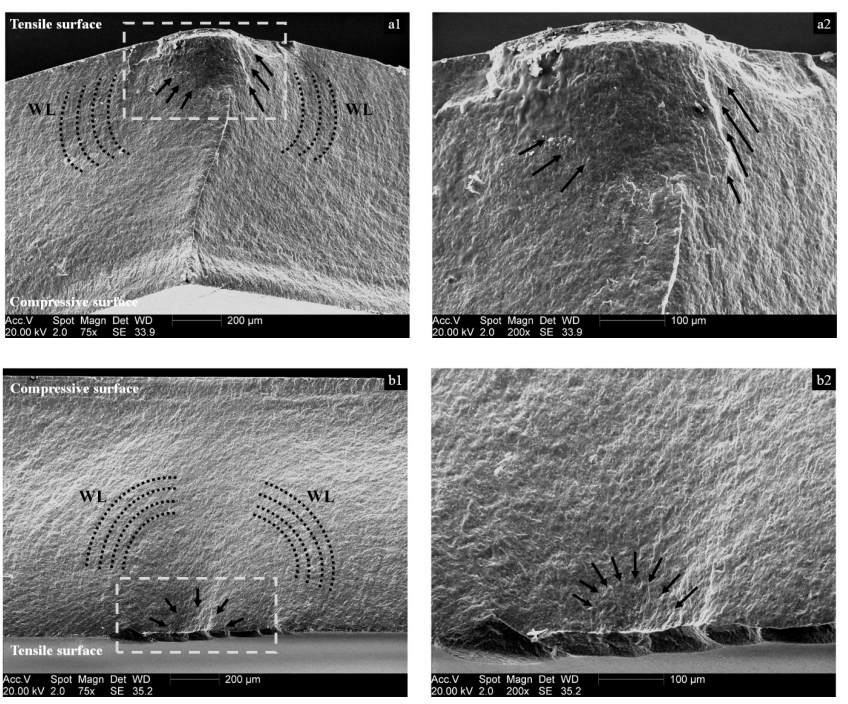

Figure 2: Scanning electron microscopy images of the fracture surfaces of disc (a1, a2) and square plate (b1, b2) ceramic specimens. The failure originated from the tensile surface, regardless of the sample geometry. In the images a1 and b1 it is possible to see typical Wallner lines (WL - black dashed curves). It is also possible to observe the presence of hackles (black arrows) pointing to the origin of the failure. A higher magnification of the failure origin zone (white dashed lines) is shown in a2 and b2.

[Figura 2: Micrografias obtidas por microscopia eletrônica de varredura de superfícies fraturadas de corpos de prova cerâmicos no formato de disco (a1, a2) e quadrado $(b 1, b 2)$. A falha teve origem na superfície sujeita a tensão de tração durante o ensaio, independente da geometria do corpo de prova. Nas imagens al e bl é possível observar a presença de típicas linhas de Wallner (WL - curvas pontilhadas em preto). Também é possível observar a presença de hackles (setas pretas) apontando para a origem da fratura. As regiões de origem da falha (linhas brancas pontilhadas) em maior aumento são apresentadas em a 2 e b2.] 
a light increase.

The pattern of stress distribution was very similar for D and S specimens (Fig. 1); a cloverleaf-shaped stress field can be clearly recognized, which appears among the three supporting balls. The fractographic analysis showed that D and S specimens had a similar pattern of failure. The SEM images of the fractured specimens confirmed that the failure originated from the surface submitted to tensile stress during the flexural test (Fig. 2), regardless of the sample geometry (disc or square plate).

\section{DISCUSSION}

Biaxial flexure tests are widely employed to evaluate the mechanical behavior of dental ceramics. They create a state of biaxial stress which simulates better the multiaxial stress condition that restorative materials are subjected during function, does not discriminate cracks in particular orientations, and avoid undesirable edge fractures $[7,8]$. The present study was conducted to evaluate the possibility of simplifying the confection of specimens for piston-on-three ball biaxial flexure tests employing CAD/CAM ceramic blocks. The use of square plate specimens, instead of disc specimens, as suggested by the International Standard for Dentistry Ceramic Materials [3], should expedite the sample preparation, as many CAD/CAM ceramics are available in cuboid shaped blocks. A modification in the ISO 6872:2008, allowing the use of square or rectangular plates in the pistonon-three ball test, would be very important to reduce the time and the costs involved in the confection of CAD/CAM ceramic specimens. While this modification does not occur, the present study showed that square plate specimens may be considered an alternative to optimize sample preparation for piston-on-three ball tests in CAD/CAM ceramics. To calculate the flexural strength, using the ISO 6872:2008 formulas, the disc radius value may be replaced by the half side length of the square plate. Considering this, the null hypothesis that disc and square plate ceramic specimens, with the same lower (tensile) surface area, would show a similar behavior in terms of flexural strength was accepted.

A good agreement between biaxial strength values has been reported for circular- and square-shaped specimens tested in different configurations, such as ball-on-threeballs [8, 14] and ball-on-ring-of-balls [15]. In these studies, to calculate the strength of plate specimens, mathematical adaptations were performed in the formulations standardized for disc specimens. The ball-on-three-balls test assumes a mirror-symmetry when rectangular plates are used, losing the three-fold symmetry acquired with disc-shaped samples [8]. The extra material on the edges of the plates may stiffens the specimens, interfering in the bending strain, and requiring special numerical analysis to calculate the strength [8]. In the present study, to calculate the biaxial strength value, using the ISO 6872:2008 formula, the authors just substituted the required value of the radius of the disc by the one-half of the edge length of the square plate specimen. However, for the same test condition, the difference obtained between the experimental and FEA values was higher for S group (99 $\mathrm{MPa}$ in FEA and $84 \mathrm{MPa}$ in the experimental test) than for $\mathrm{D}$ group (99 $\mathrm{MPa}$ in FEA and $95 \mathrm{MPa}$ in the experimental test). Considering this, an underestimation (around 15\%) of the strength values may be expected when applying ISO formulations for square plate specimens. Therefore, it is not recommended comparison between different specimen geometries in the same study. Future studies should focus on adaptations on the ISO 6872:2008 formula to calculate the biaxial strength of square and rectangular plate specimens, such as the formula existing for ball-on-three-balls test [14].

The first principal stress of D and S was very similar in the conditions 1 to 4 of the FEA, where the discs and the square plates had the same lower (tensile) surface area. When the disc radius was equivalent to half side length of the square (conditions 1 to 5), this similarity remained, which may indicate that, for small differences in the lower (tensile) surface area, a similar flexural strength may be expected for discs and plates. However, an experimental test, comparing the monotonic strength of discs and square plates with different surface areas, in which the radius of the disc was equal to the half side length of the plate, should be performed to confirm this hypothesis. The pattern of stress distribution (Fig. 1) indicated that the volume under higher tensile stresses was concentrated in the middle of the circle formed by the three supporting balls, irrespective of the specimen geometry. The tensile stresses gradually decrease from the center to the boundaries of the specimens. The edges of the square plate specimens, potential concentrators of stress, were positioned outside of the circle created by the supporting balls and far from the point where the load was applied.

The number of fragments generated by the fracture depends upon the stress state throughout the specimen and the total energy available for fracture [5]. It has a positive correlation with the ceramic flexure strength [16], in which low energy fracture results in few fragments, while high energy fractures result in extensive fragmentation. In the present study, a low number of fragments (two in the most of cases) was generated in both $\mathrm{D}$ and $\mathrm{S}$ groups, indicating that a similar low energy was necessary to promote the fracture in disc and square plate specimens. The fractographic analysis of the fractured specimens (Fig. 2) showed that the fracture started from the surface subjected to tensile stresses during the test, with a similar fracture origin for both geometries. The purpose of the fractographic analysis was to evaluate the failure pattern of the discs and square plates, ensuring that the fracture started from the surface submitted to tensile stresses during the biaxial flexural test and not from the contact surface between the specimen and the piston. The classification of the defect that originate the failure into volume located, surface located and near-surface located was not the purpose of the present study.

In piston-on-three ball tests, sample preparation requires special care. According to ISO 6872:2008 [3], opposing faces of the specimen have to be flat and parallel to within $0.05 \mathrm{~mm}$, avoiding any misalignment between the loading 
piston and the three supporting balls. Another concern about some biaxial flexure configurations is the effect of friction between the specimen and the loading and support devices on the strength values. A film of non-rigid material, as a polyethylene sheet, placed in the interface between the specimen and the supporting balls and between the specimen and the piston has been indicated to reduce the friction effects, besides to permit slight out-of-flatness [3, 17]. Besides, the use of a flat piston requires a specimen with a flat surface, which does not occur with other test configurations as ball-on-three-balls [18].

Instead of using Weibull statistics, in the present study, the strength data were analyzed by a parametric test, since the data presented homogeneity of variances $(p>0.05$ based on the Levene test) and normal distribution ( $p>0.05$ based on the Shapiro-Wilk test). The strength data of brittle materials typically fit in the Weibull distribution. However, a Weibull distribution function has to be measured in at least 30 samples, which increases the costs for specimen preparation [19]. The statistical power of the present study was $82.33 \%$, indicating that the sample size used was sensible to detect a possible difference between the groups. Finally, it is important to highlight that the results of the present study are valid for glass-ceramics and are limited to the experimental conditions employed in monotonic test. Despite the use of the half side length of the square in the ISO 6872:2008 formula have resulted in similar values of biaxial flexural strength for square plates and discs, with the same lower (tensile) surface area, the influence of the geometry of the specimen on the flexural strength and stress distribution may vary depending on the specimen size and material's physical properties, as modulus of elasticity and Poisson's ratio. Therefore, a systematic study evaluating different ceramic materials, with different geometry and size, should be designed to better clarify this question.

\section{CONCLUSIONS}

Square plate CAD/CAM glass ceramic specimens can be used in piston-on-three-ball tests, as they showed biaxial flexure strength values similar to disc specimens. This conclusion is limited to the experimental conditions employed in the monotonic test and it is valid for the use of
ISO formulas, where the disc radius value should be replaced by the half side length of the square plate. However, flexural strength values obtained from discs and from square plates should not be compared in the same study.

\section{REFERENCES}

[1] J.R. Kelly, Dent. Mater. 11, 2 (1995) 103.

[2] A. Della Bona, Y. Dal Bello, S.C. Sartoretto, Braz. Dent. J. 23, 5 (2012) 471.

[3] Int. Org. Standard., ISO 6872, "Dentistry - ceramic materials", Geneva, 2008.

[4] R. Berenbaum, I. Brodie, Br. J. Appl. Phys. 10, 6 (1959) 281.

[5] G.D. Quinn, Fractography of ceramic and glasses, U.S. Gov. Print. Office, Washington (2007).

[6] S. Ban, K.J. Anusavice, J. Dent. Res. 69, 12 (1990) 1791.

[7] L. Sadighpour, F. Geramipanah, B. Raeesi, J. Dent. (Tehran) 3, 3 (2006) 143.

[8] M. Wendler, R. Belli, A. Petschelt, D. Mevec, W. Harrer, T. Lube, R. Danzer, U. Lohbauer, Dent. Mater. 33, 1 (2017) 99.

[9] D.K. Shetty, A.R. Rosenfield, P. McGuire, G.K. Bansal, W.H. Duckworth, Am. Ceram. Soc. Bull. 59, 12 (1980) 1193. [10] J.R. Kelly, Dent. Clin. North. Am. 48, 2 (2004) 513.

[11] R.W. Li, T.W. Chow, J.P. Matinlinna, J. Prosthodont. Res. 58, 4 (2014) 208.

[12] R. Giordano, J. Am. Dent. Assoc. 137 (2006) 14S.

[13] I. Vivadent, IPS Empress $\mathrm{CAD}^{\circledR}$ : scientific documentation, Liechtenstein (2006) 31.

[14] R. Danzer, P. Supancic, W. Harrer, J. Ceram. Soc. Japan 11, 1335 (2006) 1054.

[15] C.T. Bodur, J. Aust. Ceram. Soc. 50, 2 (2014) 126.

[16] P.P. Kist, I.L. Aurélio, M. Amaral, L.G. May, Cerâmica 62,362 (2016) 121.

[17] R. Morrell, N.J. McCormick, J. Bevan, M. Lodeiro, J. Margetson, Br. Ceram. Trans. 98, 5 (1999) 234.

[18] D.C. Cranmer, D.W. Richerson, Mechanical testing methodology for ceramic design and reliability, Marcel Dekker, New York, USA (1998) 141.

[19] R. Danzer, P. Supancic, J. Pascual, T. Lube, Eng. Fract. Mech. 74, 18 (2007) 2919.

(Rec. 27/04/2017, Rev. 30/06/2017, 17/07/2017, Ac. 24/07/2017) 